\title{
Development of Bioactive Patch for Maintenance of Implanted Cells at the Myocardial Infarcted Site
}

\author{
C. Castells-Sala, ${ }^{1}$ A. Vallés-Lluch, ${ }^{2}$ C. Soler-Botija, ${ }^{3}$ \\ M. Arnal-Pastor, ${ }^{2}$ C. Martínez-Ramos, ${ }^{2}$ T. Fernandez-Muiños, ${ }^{1}$ \\ N. Marí-Buyé, ${ }^{1}$ A. Llucià-Valldeperas, ${ }^{3}$ B. Sanchez, ${ }^{4}$ J. C. Chachques, ${ }^{5}$ \\ A. Bayes-Genis, ${ }^{3}$ M. Monleón Pradas, ${ }^{2}$ and C. E. Semino ${ }^{1}$ \\ ${ }^{1}$ Department of Bioengineering, IQS-School of Engineering, Ramon Llull University, 08017 Barcelona, Spain \\ ${ }^{2}$ Center for Biomaterials and Tissue Engineering, Universitat Politècnica de València, 46022 Valencia, Spain \\ ${ }^{3}$ Heart Failure and Cardiac Regeneration (ICREC) Research Program, Health Research Institute Germans Trias i Pujol (IGTP), \\ Cardiology Service, Hospital Universitari Germans Trias i Pujol, 08916 Badalona, Spain \\ ${ }^{4}$ Division of Neuromuscular Diseases, Department of Neurology, Beth Israel Deaconess Medical Center, \\ Harvard Medical School, Boston, MA 02215-5491, USA \\ ${ }^{5}$ Laboratory of Biosurgical Research, University of Paris Descartes, Pompidou Hospital, 75015 Paris, France
}

Correspondence should be addressed to C. E. Semino; carlos.semino@iqs.url.edu

Received 9 November 2014; Accepted 16 February 2015

Academic Editor: Zhenhui Kang

Copyright (C) 2015 C. Castells-Sala et al. This is an open access article distributed under the Creative Commons Attribution License, which permits unrestricted use, distribution, and reproduction in any medium, provided the original work is properly cited.

Ischemia produced as a result of myocardial infarction might cause moderate or severe tissue death. Studies under development propose grafting stem cells into the affected area and we hypothesize that this mechanism could be enhanced by the application of a "bioactive implant." The implant herein proposed consists of a thin porous elastomeric membrane, filled with self-assembling nanofibers and human subcutaneous adipose tissue derived progenitor cells. We describe the development and characterization of two elastomeric membranes: poly(ethyl acrylate) (PEA) and poly(caprolactone 2-(methacryloyloxy)ethyl ester) (PCLMA). Both are a good material support to deliver cells within a soft self-assembling peptide and are elastic enough to withstand the stresses arising from the heartbeat. Both developed composites (PEA and PCLMA, combined with self-assembling peptide) equally facilitate the propagation of electrical pulses and maintain their genetic profile of the seeded cells. Preliminary studies with small animal models suggest that, at short times, the bioimplant shows good adhesion with the myocardium. After three days cells loaded in the patch remain alive at the implanted site. We propose that the bioactive patch (elastomeric membranes with self-assembling peptide and cells) could increase the efficacy of future cardiac cell therapy by improving cell immobilization and survival at the affected site.

\section{Introduction}

Heart failure (HF) is the end stage of most cardiovascular diseases such as myocardial infarction (MI), which remains the leading cause of premature death in the world. MI is caused by a coronary artery occlusion that provokes a reduction of blood supply to a portion of the myocardium, developing a necrotic tissue with subsequent cell death [1]. Current therapies to reestablish blood supply to the affected tissue include percutaneous coronary intervention (PCI), stent placement, coronary artery bypass surgery, and drugs administration. These treatments are capable of increasing patients' life expectancy but do not address the malfunction due to muscular tissue death. In parallel, growing evidences indicate that heart muscle is capable of regenerating through the activation of cardiac stem cells or recruitment of stem cells from other tissues [2], but it is not enough to compensate the large-scale tissue loss after MI. The implantation of cells with the hope that they will contribute to the generation of new cardiac tissue appears as a good approach [3-5]. Several cell types are being tested as a potential source for cell therapy including cardiac myocytes, skeletal myoblasts, 
embryonic stem cells (ESCs), and adult stem cells (ASCs) $[2,6-12]$. ASCs are present in various organs and tissues including bone marrow [13, 14], adipose tissue [14-19], and umbilical cord $[20,21]$. Their principal advantages are based on the fact that they can be isolated from the own patient (autologous) and present a low risk of generating an immune response and tumour development. The benefits reported for cardiomyoplasty lead cells-based therapies to turn into new hope in regenerative medicine and are undergoing experimental and clinical trials. Unfortunately, until now, cell transplantation has not achieved clear hemodynamic benefits for myocardial diseases $[22,23]$. The main obstacle is that MI is an ischemic event followed by inflammatory reaction, cytokines, and growth factors secretion. Therefore, the transplantation of unprotected cells into this environment results in significant cell death and low cell bioretention and engraftment [24]. In this context, it seems suitable to provide a safe environment (niche) for cell proliferation and differentiation [23]. On the other hand, extracellular matrix that gives structural strength to the LV is pathologically modified (collagen type I decreased from $80 \%$ to $40 \%$ ) and a fibrous scar is formed [22]. Therefore, cardiomyocytes death and scar formation modulate cardiac remodeling, which refers to the changes in size, shape, structure, and physiology of the heart. The regional structural changes lead to global LV geometric change (dilated cardiomyopathy), altering fiber direction and diminishing function. This contributes to an increase in LV wall stress and mitral valve regurgitation [23].

Nowadays, a definitive statement about TE and biomaterials fields cannot be done, but there are some reliable remarks referred to as materials-based platforms: they provide mechanical support to the damaged tissue while it regenerates, can be modified to supply the bioactive agents necessary for regeneration, and are able to restrict the cells to the defect site guiding cell growth through surface chemistry and topography [25]. RECATABI consortium proposes an approach to address both the death of cardiomyocytes and the remodelling of the heart muscle, with the aim to avoid heart failure. The strategy consists in the development of a bioengineering platform that contains three main components: (1) elastomeric microporous membrane, which provides biomechanical support, (2) self-assembling peptide nanofiber gel, which assures an adequate microenvironment, and (3) subcutaneous adipose tissue derived progenitor cells (subATDPCs) [26]. Each of the components used to develop the patch is not novelty by themselves but the right combination of them is.

Since the activity of heart muscle involves both contraction and dilation, the use of elastomeric membranes may provide restoration forces. In addition, it is conceivable that the transmitted stresses to the engrafted cells allow deep structural and functional biointegration. With the hope to introduce a new insight, materials used for the first time in this field were examined. Complete biodegradation of grafted scaffolds may compromise long-term limitation of postischemic ventricular remodeling. For this reason, nondegradable poly(ethyl acrylate) (PEA) with cylindrical orthogonal pores and semidegradable poly(caprolactone 2(methacryloyloxy) ethyl ester) (PCLMA) with interconnected spherical pores) membranes were tested [23]. PEA has mechanical properties in the range of those of soft biological tissues and it has shown excellent biological performance in vitro with different cell types [27-33]. On the other hand, PCLMA, also elastomeric at body temperature, has a biologically stable skeleton with a biodegradable lateral chain of caprolactone. It has been chosen to carry out these preliminary in vivo experiments for its outstanding biological behaviour, tested with several architectures and cell types, both in vivo and in vitro [34-36]. The elasticity of these polymers at physiological temperature is expected to permit their adaptation to the curved ventricle over their entire surface and follow its mechanical deformation. This elastic property is crucial to not disturb the synchronous beating, and at the same time, to avoid further dilatation. It is also expected to allow the transfer of cells from the patch to the myocardium due to its good tissue-material biointegration.

The RAD16-I self-assembling peptide nanofibers (proved to be nontoxic in vivo [37]) were chosen to provide a suitable environment to the implanted cells. It has been proved to be a good candidate to culture different cell types in a 3D environment [38-43], but its soft nature is a drawback for its direct implantation as a cell vehicle. Nonetheless, it has also been described to improve cell attachment in polymeric scaffolds with respect to bare ones [44-46]. Here we propose that the combination of RAD16-I and elastomeric scaffolds should overcome the shortcomings of the gel combining the advantages of both materials.

In the present work, we study the mechanical and biological properties of the developed bioactive patch as well as a preliminary assessment of their early response, 3 days after implantation, in small animal model (mice) of acute MI. As stated, the elastomeric scaffolds employed possess different architectures and compositions and thus slightly different mechanical properties, degradability, and biological performance. It is not intended to compare both structures and chemistries, nor to study their effects in terms of cardiac tissue regeneration, but to develop "proof of concept" and demonstrate their suitability for the proposed application in terms of manipulability and applicability onto the infarcted area in the affected ventricle.

\section{Materials and Methods}

2.1. Preparation of the Elastomeric Membranes (Macroporous Scaffolds). Poly(ethyl acrylate) (PEA) scaffolds with interconnected cylindrical orthogonal pores were obtained by the template leaching method described before [47-49]. On the other hand, poly(caprolactone 2-(methacryloyloxy)ethyl ester) (PCLMA) scaffolds with spherical interconnected pores were obtained by a procedure analogous to that followed by Escobar Ivirico et al. [34]. For detailed methods, please refer to the Supplementary Materials and Methods section in the Supplementary Material available online at http://dx.doi.org/10.1155/2015/804017. Finally, both materials were washed with water and dried. PEA and PCLMA scaffolds were cut into samples having $5 \mathrm{~mm}$ in diameter and $1 \mathrm{~mm}$ thickness. Bulk films of both materials obtained by polymerization in flat glass moulds were prepared to be 
used as controls. Materials to be used for cell culture were previously sterilized with gamma radiation.

\subsection{Preparation of the Elastomeric Membrane Prefilled with} RAD16-I Self-Assembling Peptide Nanofiber Scaffolds (Composite). The self-assembling peptide RAD16-I (PuraMatrix $1 \%(\mathrm{w} / \mathrm{v}), \mathrm{BD}$ Biosciences) was used to fill the PEA and PCLMA scaffolds' pores. Prior to its use, RAD16-I was placed in a bath sonicator (Bandelin) for $30 \mathrm{~min}$ at $25^{\circ} \mathrm{C}$ applying $30 \mathrm{~W}$ to decrease its viscosity and diluted to $0.15 \%(\mathrm{w} / \mathrm{v})$. Each elastomeric membrane was submerged in a RAD16I nanofiber peptide $0.15 \%$ solution, and with the help of vacuum it was forced to penetrate in the hydrophobic scaffolds. For the induction of the self-assembly of RAD16-I, it is imperative to increase the ionic strength of the milieu. For experiments without cells the self-assembling was induced with phosphate buffer saline (PBS), but for the preparation of bioimplant containing RAD16-I and cells the gelation of RAD16-I was performed simultaneously to the seeding process [45]. The process is explained in Section 2.4. The efficient filling of membranes and gelling of RAD16-I were assessed macroscopically by $\beta$-sheet structure staining with Congo Red $0.1 \%$ (w/v) aqueous solution (Sigma Aldrich) for $20 \mathrm{~min}$ followed by $30 \mathrm{~min}$ of rinsing with PBS. Scaffolds with only PBS in their pores were stained to be used as controls. Next, cryoSEM images of the composites were obtained by cryoSEM in a JSM5410 (JEOL Ltd., Tokyo, Japan) device equipped with a cryounit (Oxford CT 1500) to confirm the uniform filling of the scaffolds with the peptide gel. Cross sections were previously obtained by immersion of the samples in liquid nitrogen. Water within the peptide gel was sublimated at $-70^{\circ} \mathrm{C}$ in the cryogenic unit for $15 \mathrm{~min}$ in vacuum. Samples were gold-sputtered and observed at $15 \mathrm{kV}$ and $15 \mathrm{~mm}$ of working distance.

\subsection{Structural, Mechanical, and Electrical Characterization of the Elastomeric Membranes and Its Composites}

2.3.1. Morphology. Bare PEA and PCLMA scaffolds were fixed in 5\% glutaraldehyde (Sigma Aldrich), dehydrated in successive ethanol washes, dried using a $\mathrm{CO}_{2}$ critical point, and subsequently coated with gold. Samples were observed in a JSM 6300 (JEOL Ltd., Tokyo, Japan) scanning electron microscope (SEM) at $15 \mathrm{kV}$ of acceleration voltage and $15 \mathrm{~mm}$ of working distance. The porosity of the bare scaffolds, $\pi$ (pore volume fraction), was obtained through the specific volume of PEA (reciprocal of $1.13 \mathrm{~g} \cdot \mathrm{cm}^{-3}$ ) [50] or PCLMA, respectively, $v$, the weight, $m$, and apparent (geometric) volume, $V$, of the scaffolds as $\pi=V^{\text {pores }} / V=1-m v / V$. The specific volume of PCLMA was previously obtained as follows: dry pieces of PCLMA films were weighed in air, $m$, and immersed in n-octane $\left(95 \%\right.$, Fluka, $\rho_{\mathrm{n} \text {-octane }}=$ $\left.0.703 \mathrm{~g} \mathrm{~cm}^{-3}\right), m^{\prime}$, at room temperature. Specific volume was calculated as the volume of n-octane displaced, obtained as $V_{\text {displ }}=\left(m-m^{\prime}\right) / \rho_{\text {n-octane }}$, divided by the mass of the sample: $v=V_{\text {displ }} / m$. Mettler AX 205 balance (Mettler-Toledo Inc., Columbus, $\mathrm{OH}, \mathrm{USA}$ ) with a sensitivity of $0.01 \mathrm{mg}$, equipped with a Mettler ME 33360 density accessory kit, was used.
2.3.2. Surface Wettability. The wettability of the elastomeric membranes was assessed using a Drop Shape Analysis System DSA100 (KRÜSS, Deutschland). Briefly, water drops were deposited on the membranes and the contact angle between each drop and the surface of the membrane was measured.

2.3.3. Swelling and Tensile Properties. To quantify the swelling of the scaffolds, $5 \mathrm{~mm}$ diameter pieces of PEA and PCLMA films were dry weighed and after different times of immersion in phosphate-buffered saline (PBS) at $37^{\circ} \mathrm{C}$ until no further weight change was confirmed. The equilibrium water content (EWC) was obtained as the ratio of the mass of water absorbed at equilibrium to the mass of dry polymer: EWC = $\left(m_{\text {wet }}-m\right) / m$. Pieces of PEA and PCLMA scaffolds and their films were cut into $0.5 \times 3 \mathrm{~cm}^{2}$ pieces, and tensile tests were performed in a Microtest SCM3000 95 (Microtest SA, Madrid, Spain) device at a deformation rate of $0.2 \mathrm{~mm} / \mathrm{min}$ until fracture. The tensile modulus was obtained in each case as the average of the slope in the strain-stress plots.

2.3.4. Study of the Impedance. The electrical impedance of the membranes filled with hydrogel and submerged in $\alpha$-MEM medium (Sigma Aldrich) was measured at $10 \mathrm{kHz}$ using an impedance meter (Autolab, PGSTAT128N). Membranes filled with physiologic serum $(\rho=0.625 \Omega \cdot \mathrm{m})$ were also measured to normalize impedance values $(\Omega)$ to resistivity units $(\Omega \cdot \mathrm{m})$. Platinum electrodes $(0.5 \mathrm{~mm}$ diameter $)$ were used for measurements performed at room temperature $\left(25^{\circ} \mathrm{C}\right)$. The electrodes were introduced in parallel within the plane membrane and separated by a distance of $5 \mathrm{~mm}$.

\subsection{Cell Culture}

2.4.1. Subcutaneous Adipose Tissue-Derived Progenitor Cells (SubATDPCs) Isolation and Culture. SubATDPCs were isolated from fat pads between skin and sternum from patients undergoing cardiac surgery. Informed consent was obtained from all subjects, and the study protocol conformed to the principles outlined in the Declaration of Helsinki. Adipose tissue biopsy samples were processed as previously described $[53,54]$. Refer to Supplementary Materials and Methods section for detailed information. Adhered cells were grown under standard conditions $\left(37^{\circ} \mathrm{C}\right.$ and $\left.5 \% \mathrm{CO}_{2}\right)$ in $\alpha$-MEM (Sigma Aldrich) supplemented with $10 \%$ foetal bovine serum (Lonza), 1\% penicillin-streptomycin (Labclinics), 1\% Lglutamine (Labclinics), and $5 \mu \mathrm{g} / \mathrm{mL}$ Plasmocin (InvivoGen).

\subsubsection{In Vitro Characterization of SubATDPCs Cultured in Monolayer. SubATDPCs were characterized using clono- genic and immunosuppression assays and immunopheno- typical analysis. Additionally, assays for adipogenic and osteogenic differentiation evaluation were performed. Please refer to the online Supplementary Materials and Methods section for details of the methods.}

2.4.3. Cell Seeding in Elastomeric Membrane/Self-Assembling Peptide Composites. SubATDPCs were seeded inside the composites at passage 8 . With this aim, the elastomeric 
membranes were filled with the peptide solution as explained and placed in a 96-well plate. Then subATDPCs were trypsinized and resuspended in a final concentration of $6.25 \cdot 10^{6}$ cells $/ \mathrm{mL}$ in culture media. $40 \mu \mathrm{L}$ of this suspension was loaded on the top of each composite and incubated with soft shake during $30 \mathrm{~min}$. This time allows the cells to diffuse inside the membrane while the ionic strength of the media induces the gel of the RAD16-I. Finally $160 \mu \mathrm{L}$ of fresh media was added in each well and samples were cultured under standard conditions $\left(37^{\circ} \mathrm{C}\right.$ and $\left.5 \% \mathrm{CO}_{2}\right)$.

\subsection{In Vitro Characterization of SubATDPCs Loaded in Composites (Bioimplant)}

2.5.1. Study of Gene Expression by RT-PCR. Reverse transcription polymerase chain reaction (RT-PCR) was performed to analyse gene expression in $2 \mathrm{D}$ and bioimplant cultures. The samples were lysed, and RNA was extracted with PeqGold Total RNA kit (Peqlab) and followed by cDNA synthesis using Quantitect Reverse Transcription Kit (Qiagen) according to manufacturer protocol. PCR reaction was carried out using $30 \mathrm{ng}$ of cDNA in a final volume of $25 \mu \mathrm{L}$ containing $1 \mathrm{X}$ ThermoPol Reaction Buffer (stock 10X), 0.42 units of TAQ DNA polymerase (Sigma Aldrich), $200 \mu \mathrm{M}$ of dNTPs (Sigma Aldrich), and $0.3 \mu \mathrm{M}$ primers. The PCR took place under the following conditions: $3 \mathrm{~min}$ at $95^{\circ} \mathrm{C}$ (activation) followed by 35 cycles of $20 \mathrm{~s}$ at $94^{\circ} \mathrm{C}, 30 \mathrm{~s}$ of annealing $\left(T_{m}\right.$ dependent on primer pair; see supplementary Table 1) and $30 \mathrm{~s}$ at $72^{\circ} \mathrm{C}$. Final extension step was performed at $72^{\circ} \mathrm{C}$ during $15 \mathrm{~min}$. PCR products were size fractionated by 2 or $4 \%$ agarose gel electrophoresis, depending on the expected fragment size.

\subsection{In Vivo Characterization of the Bioactive Implant}

2.6.1. Genetic Labelling of SubATDPCs. Cells were transduced $\left(2 \times 10^{6}\right.$ transducing units $\left./ \mathrm{mL}, \mathrm{MOI}=21,48 \mathrm{~h}\right)$ with CMVpRLuc-mRFP1 lentiviral vector, which contains a chimeric construct of the Renilla reniformis luciferase (RLuc) reporter gene and monomeric red fluorescent protein (mRFP1) under transcriptional control of the cytomegalovirus (CMV) promoter [55].

2.6.2. Myocardial Infarction Model. The study was performed on 8 female SCID mice (20 to 25 g; Charles River Laboratories, Inc.). Myocardial infarction was created as previously described [18], occluding the LAD coronary artery which provokes and acute infarct. The animals were randomly assigned to one of the following groups: (1) PEA-bioimplant implantation and no MI induction (the PEA sham group, $n=2)$, (2) MI induction and PEA-bioimplant implantation $(n=2)$, (3) PCLMA-bioimplant implantation and no MI induction (the PCLMA sham group, $n=2$ ), and (4) MI induction and PEA-bioimplant implantation $(n=2)$. The bioimplants were implanted immediately after occlusion.

2.6.3. Assembly and Transplantation of the Bioimplant. The bioimplants were cultured in standard conditions for $24 \mathrm{~h}$ before implantation onto the healthy or the infarcted myocardium of mice, making use of synthetic surgical glue (Glubran 2) to fix their edges to the tissue and avoid sliding. Three-day postimplantation hearts were arrested in diastole with arrest solution $(68.4 \mathrm{mM} \mathrm{NaCl}, 59 \mathrm{mM} \mathrm{KCl}, 11.1 \mathrm{mM}$ Glucose, 1.9 mM NaHCO $3,29.7$ mM BDM (2,3-butanedione monoxime), $1000 \mathrm{U}$ Heparin). Then the samples were excised, fixed, cryopreserved in 30\% sucrose in PBS, embedded in OCT (Sakura), and snap-frozen in liquid nitrogen-cooled isopentane. Tissue blocks were stored at $-80^{\circ} \mathrm{C}$ until sectioning.

2.6.4. Noninvasive Bioluminescence Imaging (BLI) of Luciferase Activity from Bioimplant. Anesthetized mice, bearing a bioimplant seeded with PLuc expressing cells, were intraperitoneally injected with $150 \mu \mathrm{L}$ of luciferin for in vivo BLI (16.7 $\mathrm{mg} / \mathrm{mL}$ in physiological serum) (Caliper, Hopkinton, MA). Mice were monitored right after implantation and before sacrifice. Quantification and analysis of photons recorded in images were done using the Caliper image analysis software (Caliper, Hopkinton, MA).

2.6.5. Histology and Immunohistochemistry. Mouse heart cryosections were stained with Masson's trichrome (collagen: blue, myocardium: red) and photographed using a TL RCI stereoscope (Leica) for morphology evaluation. Additionally, sections were incubated with the primary antibodies against cTnI $(2 \mu \mathrm{g} / \mathrm{mL})($ Abcam $)$ and RFP $(2 \mu \mathrm{g} / \mathrm{mL})($ Abcam $)$ to enhance cells detection. Actin fibres were stained with Phalloidin Alexa568 (1:40, Invitrogen). Nuclei were counterstained with Hoechst 33342 and results were analysed with Leica TCS SP2.

2.7. Statistical Analysis. All values were expressed as mean \pm standard deviation. Samples were prepared in triplicate for each condition analysed.

\section{Results}

3.1. Composite Development (Elastomeric Membrane + RAD16-I Self-Assembling Peptide). The architecture of developed scaffolds was analysed by SEM in a frontal view and cross section (Figure 2).

Cylindrical interconnected orthogonal pores of PEA scaffold can be clearly observed in a cross section image (Figure 2(b)) and different layers of cylindrical crossed pores in parallel and perpendicular planes can be visualized (Figure 2(a)). On the other hand, interconnected spherical pores of PCLMA scaffolds can be easily appreciated providing a trabecular regular aspect (Figures 2(e) and 2(f)).

The measured porosities of both types of scaffolds, swelling in PBS, water contact, angle, and their apparent tensile moduli (together with the tensile moduli of the bulk respective samples) are listed in Table 1. Although the values obtained for PCLMA scaffolds are slightly higher than those for PEA; for both it can be stated that they are highly porous and have a hydrophobic character and elasticity typical of elastomeric polymers. Since they differ in their chemical 
TABLE 1: Structural and mechanical parameters of the elastomeric membrane. Morphological parameters (porosity, $\pi$, equilibrium water content in PBS, EWC, water contact angle and Young modulus, $E$ ) of PEA scaffolds with cylindrical orthogonal pores and PCLMA scaffolds with spherical pores. Young modulus between brackets corresponds to the bulk PEA and PCLMA polymers.

\begin{tabular}{|c|c|c|c|c|}
\hline & $\pi(\%)$ & EWC (\%) & $\begin{array}{l}\text { Contact } \\
\text { angle }\left(^{\circ}\right)\end{array}$ & $E(\mathrm{MPa})$ \\
\hline PEA & $76.4 \pm 6.1$ & $1.14 \pm 0.16$ & $115 \pm 0.95$ & $\begin{array}{c}0.04 \pm 0.02 \\
(0.84 \pm 0.08)\end{array}$ \\
\hline PCLMA & $89.0 \pm 1.0$ & $10.00 \pm 0.73$ & $123.46 \pm 1.50$ & $\begin{array}{c}0.40 \pm 0.08 \\
(0.73 \pm 0.07)\end{array}$ \\
\hline
\end{tabular}

composition and architecture (sizes and shape of pores and interconnectivity), their biological performances will likely be different.

The Young moduli herein obtained may differ slightly when the scaffolds are filled with the weak peptide hydrogel gel and loaded with cells. Nonetheless, it can be safely stated that the stiffness of any of the proposed cardiac patches will closely match the values reported for the heart muscle of mice after dissection $(0.06 \mathrm{MPa})$ and the ones of rat or human $(0.14$ or $0.2-0.5 \mathrm{MPa}$, resp., at the end of diastole) $[12,56,57]$.

The loading of the self-assembling peptide RAD16-I into the elastomeric membranes was carried out prior to the loading of the cells. Both elastomeric membranes are hydrophobic (none of them swells more than 10\% in PBS, Table 1). For this reason, vacuum was used to force the viscous self-assembling peptide solution to get into the membrane, and a subsequent in situ gelling was carried out successfully with the diffusion of an ionic solution. The positive Congo red staining (Figures 2(c) and 2(g)) indicates that the formation of the gel leads to a $\beta$-sheet structure and the cryoSEM images (Figures 2(d) and 2(h)) confirm that the scaffolds' pores are uniformly filled with the peptide gel. The hydrogel is shown as a honeycomb-like structure after sublimation of water. Although the quantity of RAD16-I cannot be quantified, the complete filling of the pores has been assessed.

3.2. Electrical Resistivity of the Composites. The electrical resistivity of the composites was analysed, and data were normalized. Electrical resistivity of $53.0 \pm 8.5 \Omega \cdot \mathrm{m}$ was obtained for PEA membrane while $52.8 \pm 5.5 \Omega \cdot \mathrm{m}$ was obtained for PCLMA (Table 2). By comparing PEA and PCLMA membranes, it can be observed that both membranes studied present similar electrical resistivity.

3.3. In Vitro Characterization of SubATDPCs Cultured in Monolayer. SubATDPCs were spindle-shaped and clonogenic and had a duplication time of $3.1 \pm 0.03$ days at passage 2 when seeded at a density of 1000 cells $/ \mathrm{cm}^{2}$ (Supplementary Figure 1A). Immunophenotypical characterization of the cells revealed a mesenchymal stem-cell- (MSC-) like pattern, with a high percentage of subATDPCs staining strongly positive for CD105, CD44, CD166, CD29, and CD90 and negative for CD106, CD45, and CD14 (Supplementary Figure $1 \mathrm{~B})$. Comparable to the case of bone marrow-derived
TABLE 2: Electrical parameters of the composite. Electric impedance values at $10 \mathrm{KHz}$ for PEA and PCLMA scaffolds previously filled with RAD16-I 0.15\% self-assembling peptide and healed transmural and nontransmural myocardium.

\begin{tabular}{lc}
\hline & $\rho(\Omega \mathrm{m})$ \\
\hline PEA & $53.0 \pm 8.5^{\mathrm{a}}$ \\
PCLMA & $52.8 \pm 5.5^{\mathrm{a}}$ \\
Infarcted nontransmural myocardium & $122 \pm 27^{\mathrm{b}}$ \\
Infarcted transmural myocardium & $104 \pm 31^{\mathrm{c}}$ \\
\hline${ }^{\mathrm{a}}$ In work. & \\
${ }^{\mathrm{b}}[51,52]$. & \\
${ }^{\mathrm{c}}[52]$. &
\end{tabular}

MSCs [58], subATDPCs were able to inhibit peripheral blood lymphocyte proliferation (an 82\% proliferation reduction), indicating an immunosuppressive capacity of subATDPCs. Moreover, culture of subATDPCs in adipogenic or osteogenic differentiation media resulted in intracellular accumulation of lipid droplets and calcium deposition, respectively, indicating adipogenic and osteogenic differentiation potentials (Supplementary Figure 1C) [59]. In addition, these cells have been analyzed for the expression of cardiac markers and their cardiac differentiation under electric stimulus by LluciàValldeperas et al. [60].

3.4. Bioimplant Preparation (Elastomeric Membrane + RAD16-I Self-Assembling Peptide + SubATDPCs). Once assessed the correct introduction of RAD16-I nanofiber peptide inside the elastomeric membrane, subATDPCs suspended in medium were loaded on the constructs.

During shaking, the cells were allowed to diffuse while the high ionic strength of the media induced the selfassembly of RAD16-I. After 1 and 4 days of in vitro culture, the bioimplants were removed from the well plate, and we analysed gene expression. The morphology of the cells after 7 days of in vitro culture can be observed in Figure 3. Cells grew mostly at the surface of the construct of both types of elastomeric membranes, indicating that, in vitro, they were unable to invade the scaffolds completely. The surfaces were, though, totally covered by cells after this culture time. DAPI/Phalloidin staining in Figures 3(g) and 3(h) shows how some cells have been able to migrate inside the construct during the first days of culture, but most remain on the surface.

3.5. Study of Gene Expression by RT-PCR. RT-PCR analysis was performed to assess the possible cardiac profile of the cells after 1 and 4 days (Figure 4 ) of culture. Day 1 samples show gene profile before implantation of the bioimplants in mice, and day 4 presents gene profile of the bioimplant cultured in vitro for 4 days, which coincides with the length of the in vivo experiments (1 day of preculture and 3 days of follow-up after implantation). Interestingly, expression of early cardiac markers such as TBX5 (T-box transcription factor 5), MEF2C (Myocyte Enhancer Factor 2C), and some definitive cardiac markers such as ACTN1 (Actinin, alpha1), cTnT (Troponin T2), and GJAI (Connexin-43) can 

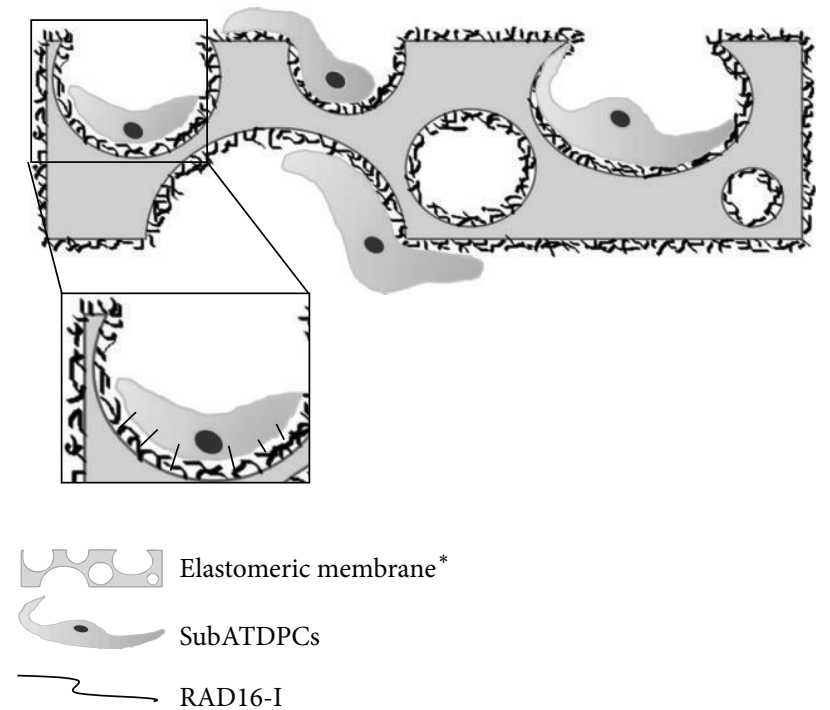

FIGURE 1: RECATABI concept scheme. Elastomeric membrane pores completely filled with the self-assembling peptide RAD16-I and subATDPCs growing on and inside the composite. ${ }^{*}$ The pores of the scheme are spherical but different architectures can be used.

be observed. Additionally, expression of CDH1 (E-Cadherin) and SNAI1 (Snail Family Zinc Finger 1, a natural repressor of CDH1) were analysed.

No important differences were detected between day 1 and day 4 on gene expression except for cTnT, which was downregulated in the composite but was upregulated again in PCLMA at 4 days of culture. In addition, the expression of $\mathrm{CDH} 1$ in both composite systems used was downregulated. All these results indicate that the composite is not cardioconductive since no difference between materials can be observed, but it is able to maintain the cardiac fate of subATDPCs.

3.6. In Vivo Implantation. With the intention of monitoring cell survival and distribution of the implanted cells after the bioactive patch implantation, a noninvasive bioluminescence imaging (BLI) system was used. Cells within the bioimplant were previously labelled with CMV:Rluc:RFP:ttk photoprotein reporters for BLI and fluorescence detection. Photon counts quantification showed human subATDPCs survival and thoracic location three days after implantation of PEA and PCLMA bioimplants (supplementary data). Moreover, whole heart excision and histology examination demonstrated correct position of the bioactive implant on the infarcted area (Figures 5(A)-5(D)).

Three days after implantation, subATDPCs within the PEA bioimplant were homogeneously distributed giving some of them an elongated shape (Figure 5(E)). On the other hand, PCLMA bioimplant cells were mainly distributed in the borders of the myocardium (My) or inner membrane (im) and only few were found in the outer membrane (om) (Figure 5(I)). Both bioactive implants were attached to the heart (Figures 5(C), 5(D), 5(F), and 5(I)), and few cells already started migration to the damaged myocardium (Figures $5(\mathrm{G})$ and $5(J))$.

\section{Discussion}

The high impact of MI worldwide leads a lot of researchers to focus their attention on cardiac tissue engineering (CTE) with the aim to obtain an effective approach for necrotic tissue repair. CTE's success highly depends on the choice of the appropriate cell source $[7,8]$, and the biomaterial [61] used as a vehicle to graft the cells in the infarcted tissue. Here, we propose a combination of an elastomeric membrane and a self-assembling peptide combining their intrinsic properties and obtaining a more adaptable patch. Different types of material-based approaches have been developed with the aim to improve cardiac function after myocardial infarction to avoid heart failure [62]. One of these approaches is the use of biomaterials to constrain the post-MI failing heart, preventing it from further remodeling and dilatation [6366]. Our design aims to avoid ventricle dilatation using a nondegradable or semidegradable material and at the same time provides the cells a biological, biophysical, and mechanical support for their growth, function, self-renewal, and differentiation thanks to RAD16-I peptide. We think that the combination of elastomeric membranes with self-assembling peptide RAD16-I solves both issues (see Figure 1). From macroscopically point of view the elastomeric membranes can fit the implantation site and do not affect negatively the remaining performance of the heart due to their intrinsic elasticity. These materials are elastic enough to not restrain the remaining contractility of the heart but at the same time can avoid the negative dilatation due to matrix remodeling. Additionally, they maintain their original dimensions after implantation (do not swell) and have mechanical moduli similar to soft tissues. On the other hand, RAD16-I peptide could provide an adequate interface between the elastomeric membranes and the cells, enhancing their binding, signalling, and proper interaction. 

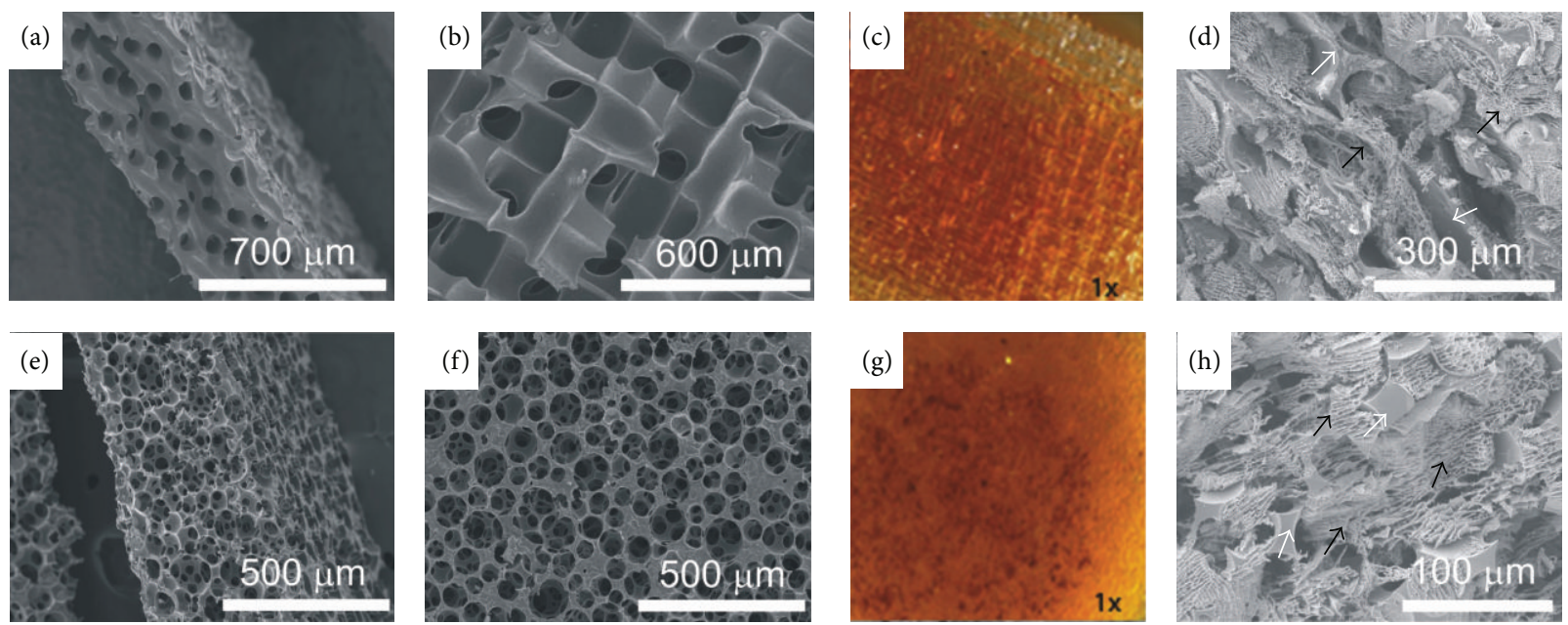

FIGURE 2: Elastomeric membrane and composite characterization. Microscopic images of the ((a)-(d)) PEA scaffolds with cylindrical orthogonal pores and ((e)-(h)) PCLMA scaffolds with spherical pores. ((a) and (e)) SEM images, cross section, and ((b) and (f)) SEM images, surface. $((\mathrm{c})$ and $(\mathrm{g}))$ Congo Red staining and $((\mathrm{d})$ and $(\mathrm{h}))$ cryoSEM images of the scaffolds loaded with 0.15\% RAD16-I and gelled with PBS, surface. White arrows point out the elastomeric membrane while the black ones point out the self-assembling peptide structure after gel.

Two chemically and architecturally different elastomeric membranes were tested: PEA scaffolds with cylindrical orthogonal pores and PCLMA ones with spherical pores. Both membranes are elastic enough to withstand the stresses arising from heartbeat and ensure stable placement of seeded cells under those conditions as it can be observed in Figure 5. With the aim to provide an adequate microenvironment, the membranes' pores were filled with RAD16-I nanofiber peptide, since previously it was demonstrated that the use of RAD16-I peptide inside the elastomeric membrane porous increases the seeding efficiency [45]. The peptide was introduced into both porous structures simply by pressure (see Figure 1). One additional advantage of these macroporous scaffolds is their capacity to allow the development of microvasculature in vivo [67]. Unfortunately, as the animal model used is analyzed at a really short term (3 days), the formation of vessels is not plausible and for this reason it was not analyzed. In vitro experiments at day 7 show a limited cell distribution with the cells remaining in the surface of the scaffold, but 3 days after implantation, cell distribution and penetration were dramatically enhanced. In vitro, the cell distribution remains mainly limited to the surface of the composite provably due to the difficulty of oxygen and nutrients diffusion inside the structure. After implantation of the patch on the infarcted heart the conditions change dramatically mainly due to the new environment, which is different from the previous culture system. Since it is a model of acute MI immediately after the intervention, the necrotic heart tissue creates an unfriendly environment which causes the implanted cells to migrate towards the contrary direction (inside the composite).

From an electrical standpoint, it is well known that the electrical resistivity is lower and less frequency dependent in necrotic than in healthy myocardium $[68,69]$. According to the values reported in Table 2, it can be observed that the resistivity values for the composites are below infarcted nontransmural and transmural myocardium resistivity, but the resistivity value of normal myocardium is larger compared to infarcted myocardium $(250 \Omega \cdot \mathrm{cm}$ at $10 \mathrm{kHz})$ [51]. We think that the resultant equivalent resistance coming from the parallel combination of the infarcted tissue and the scaffold will actually benefit the electrical coupling with native myocardium tissue. Based on the simple circuit theory principle, which confirms that the equivalent resistance of two resistances in parallel is equal or lower than the lowest resistance, the scaffold will provide a low-resistance pathway that should contribute to facilitating the electrical signal propagation from the native heart tissue into the scaffold. Thus, we speculate that both composites, which have similar electrical resistivity, will equally facilitate the propagation of electrical pulses throughout the contact area between the composites and the infarcted zone.

Since both materials presented are candidates to be used for cell therapy, they were loaded with subATDPCs (see Figure 1). The identity of progenitor cells, during early cardiogenesis, is regulated by tightly coordinated, spatially and temporally active signaling pathways and molecular mechanisms. This leads cells to a progressive restriction of undifferentiated progenitors to the different cardiovascular lineages. The molecular identity of these inductive signals is not well understood, but various transcription factors that may regulate cardiac commitment and differentiation have been isolated [70].

The in vitro genetic profiles of such cells cultured in both composites were analysed before their in vivo implantation. Interestingly, TBX5 [71, 72] and MEF2C [73] early cardiac markers and definitive cardiac markers such as ACTN1, cTNT, and GJAI were expressed [74]. TBX5 is a member of T-box gene family [75] critical for the development of the heart. Its expression is critical to the formation of the electrical system that coordinates contractions of the heart chambers. It has been shown to interact with MEF2C to 
PEA
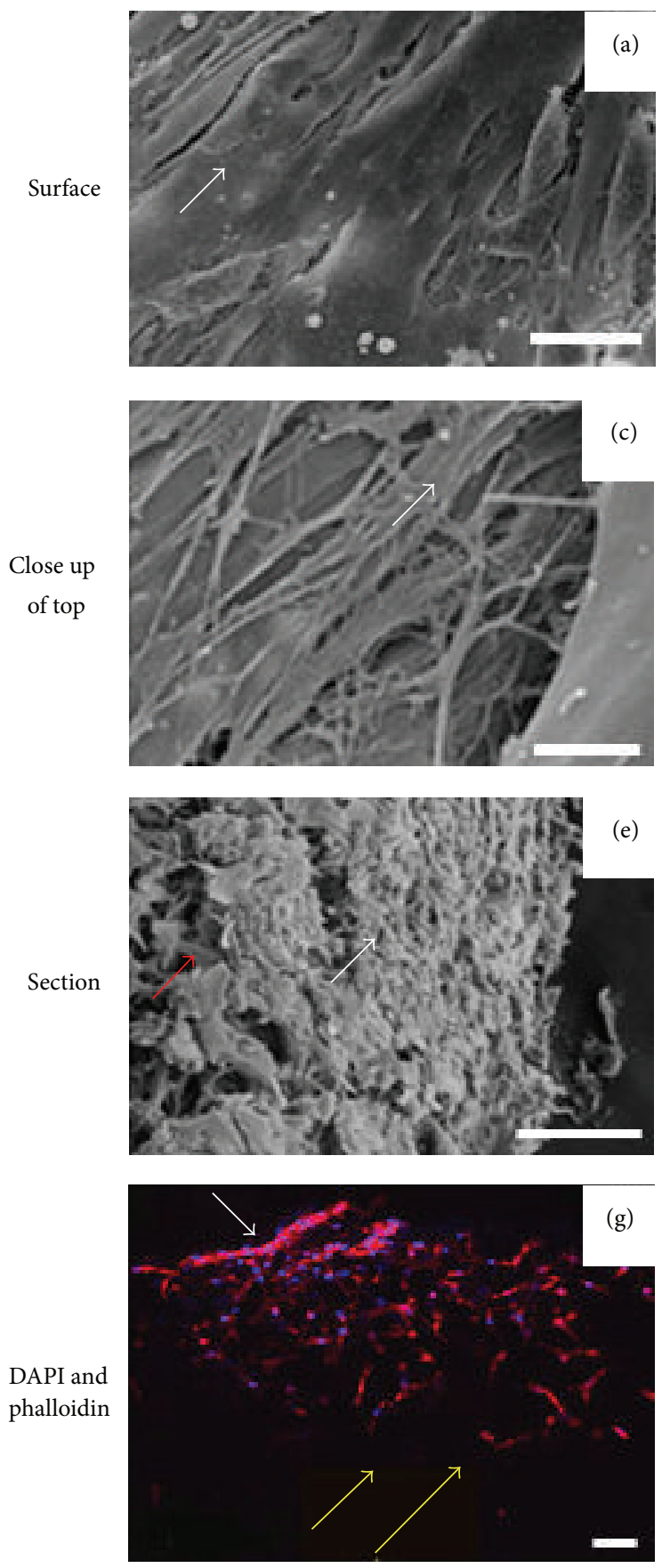

PCLMA
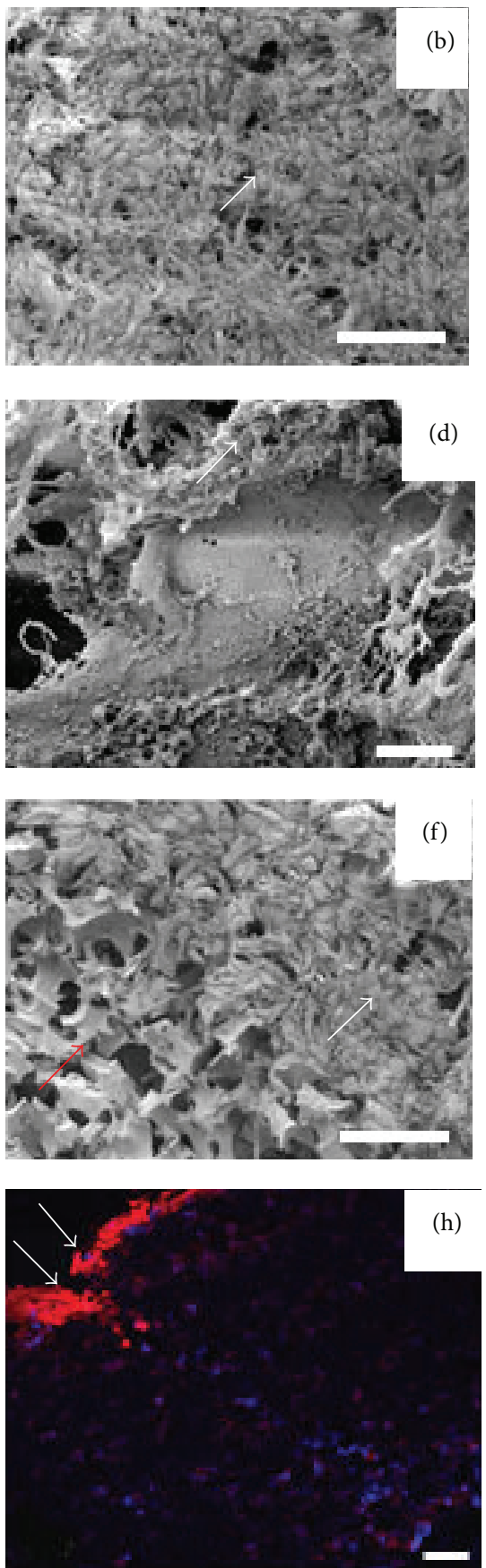

FIGURE 3: Bioimplant characterization. Microscopic images of subATDPCs growing in developed composite after 7 seeding days. (a) Surface of PEA scaffold; (b) surface of PCLMA scaffold; ((c), (d)) close up of top PEA, and PCLMA scaffold respectively; (e) PEA scaffold cross section; (f) PCLMA scaffold cross section; and ((g) and (h)) Dapi \& Phalloidin staining of subATDPCs in PEA and PCLMA scaffold. In images (a) to (f) white arrows indicate the cells growing in the bioactive implant, black arrows note the nanofibers of self-assembling peptide RAD16-I, and red arrows signalize the structure of porous elastomeric membrane. White arrows in image (g) and (h) indicate scaffolds surface while orange arrows indicate cells migrating inside the composite. Scale bars: (a) $30 \mu \mathrm{m}$; (b), (E)-(H) $100 \mu \mathrm{m}$; (c) $3 \mu \mathrm{m}$; and (d) $5 \mu \mathrm{m}$.

synergistically activate target genes expression in cardiomyocytes [72]. MEF2C is a MDS-box transcription factor which plays a key role in myogenesis [76], specifically controlling the differentiation of cardiomyoblasts into cardiomyocytes
[77] (see Figure 6). On the other hand, a decrease of CDH1 expression with respect to cells growing in 2D culture was observed, although SNAI1 repression factor was maintained. $\mathrm{CDH} 1$ and GJAI genes encode for cell connection proteins. 


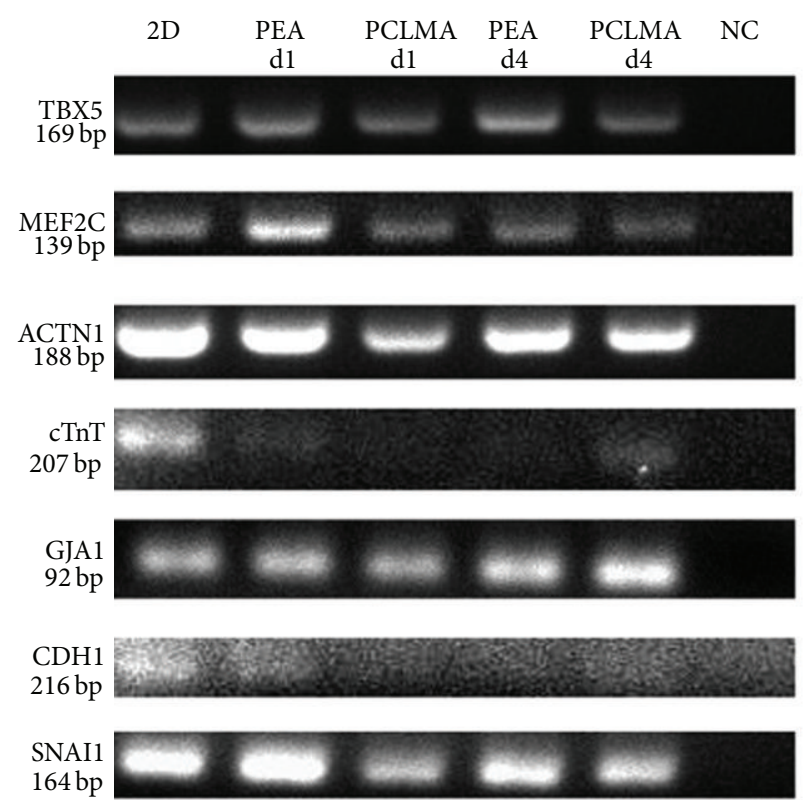

FIGURE 4: Expression of cellular markers in developed bioimplant by RT-PCR. Cardiogenic and general markers expressed by subATDPCs cultured in developed patch of PEA and PCLMA after 1 (d1) and 4 (d4) days of culture in vitro compared to two-dimensional (2D) cultures. NC: negative control (PCR without template).

CDH1 [78] is involved in mechanisms regulating cell-cell adhesions, mobility, and proliferation while GAJ1 provides a route for the diffusion of low molecular weight materials from cell to cell having a crucial role in the synchronized contraction of the heart. As suggested by the results shown in Figure 5, these cells are capable of migrating either inside the membrane or to the infarcted area after implantation. It is important to mention that most of the studied genes presented the same pattern for all conditions, but cTNT was only expressed in the PCLMA bioactive implant after 4 days in vitro. Therefore, it seems that subATDPCs are maintaining their gene profile, which indicates that they tend to preserve their cardiogenic potential lineage, at least in vitro. These results lead us to conclude that the proposed materials combined with RAD16-I are not cardioconductive materials, but the cardiomyogenic potential of subATDPCs is maintained [60].

The in vitro model gives an overview of the patch potential, but in any case these results could be extrapolated to the in vivo scenario. Here, a proof of concept of short time points was developed to analyse the patch feasibility in terms of integration and cell viability. Interestingly, we notice that both patches intimately attach to the myocardium. Additionally, both remained in the position at the infarction area where they were placed suggesting some resilience to the heart mechanical forces and, in addition, 3 days after implantation the cells remained alive and mostly at the thoracic area (Figure 2, supplementary data). Although both bioactive implants were attached to the myocardium, the PCLMA bioimplants showed greater cell immobilization and better integration in the infarcted area than the PEA ones. Cells growing inside the PEA bioimplants were homogenously distributed, acquiring some elongated shape (Figures 5(E) and $5(\mathrm{~F})$ ) while, in the PCLMA ones, cells were mainly distributed at the interface between the bioimplant and the myocardium (Figure 5(I)). We did not expect to observe profusely cell migration at such short time assay, but we speculate that the cells might start to contribute to a paracrine effect by secreting specific factors; phenomena previously reported using MSC and cardiomyocytes in rat and mice models, respectively [79-81]. Importantly, in previous studies an increase of vascularization and a reduction of infarct size after ATDPCs injection were reported [45]. Therefore, their better retention onto the infracted tissue using this platform might lead to positive benefits by the stimulation of vessel formation. Further in vivo studies at longer time points will be performed with the aim to analyse the beneficial role of these bioactive patches in vivo.

\section{Conclusions}

PEA- and PCLMA-based bioimplants developed provide a good platform for cell therapy aiming to assist tissue restoration of the infarcted ventricular area. Importantly, the scaffold plus peptide gel composite devices brings a suitable microenvironment where cells can be retained alive at the implanted site, which is an improvement of the proposed to date direct cell injection therapies. Moreover, these patches permit cells to maintain their genetic profile enhancing their therapeutic potential at the time of being implanted. Finally, all these characteristics could improve the cell capacity to provide a positive paracrine effect on resident cells in the host tissue, which might improve the recovery of the infarcted zone. 
PEA

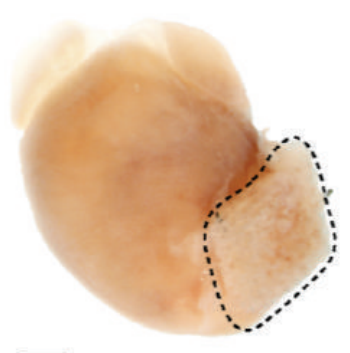

(A)

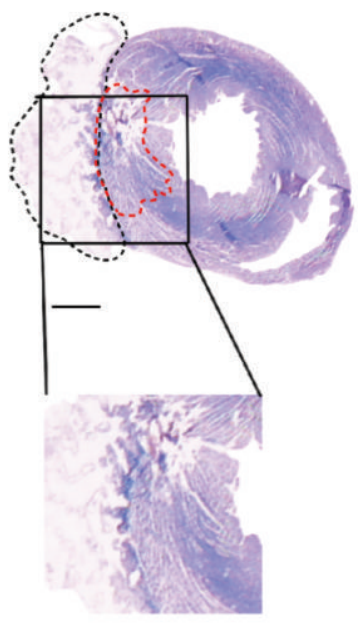

(C)
PCLMA

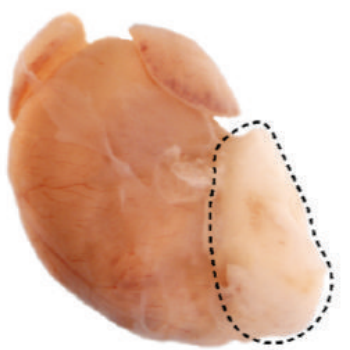

(B)

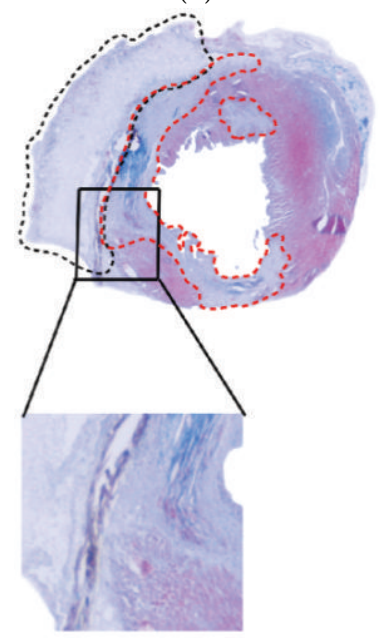

(D)

(a)
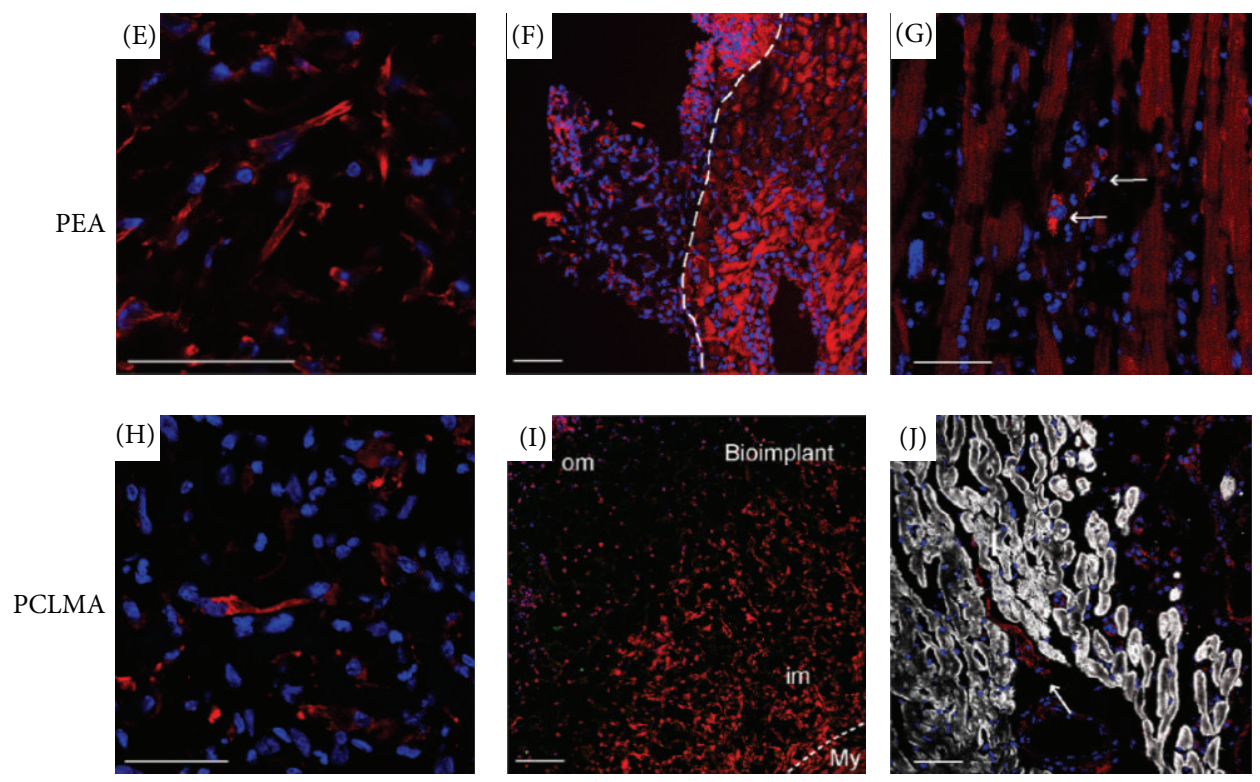

(b)

Figure 5: General view of the PEA and PCLMA bioactive implants on mice heart after 3 days. (a) Whole heart excision and macroscopic examination. ((A) and (B)) Macroscopic view of mouse heart and bioactive implant (outlined) at 3 days after implantation, and ((C) and (D)) Masson's trichrome staining of heart with bioactive implant cross section. The dotted zone in black corresponds to the bioactive implant and the dotted red area to the infarcted zone. (b) Microscopic view of the bioactive implant. ((E) and (H)) Detail of elongated subATDPCs (red) inside the PEA (E) and PCLMA (H) bioactive implants; ((F) and (I)) views of the PEA (F) and PCLMA (I) bioactive implants attached to the myocardium (implant and myocardium are limited by dotted lines (Phalloidin staining in red)); and $((\mathrm{G})$ and $(\mathrm{J})$ ) migration of the subATDPCs (white arrows) to the myocardium (cTnI staining in white) in PEA (G) and PCLMA (J) groups. Constitutive expression of RFP (red) in subATDPCs. Nuclei were counterstained with Hoescht 33342 (blue). Scale bars $1 \mathrm{~mm}((\mathrm{~A})-(\mathrm{D})), 50 \mu \mathrm{m}((\mathrm{E})-(\mathrm{H})$ and $(\mathrm{J}))$, and $100 \mu \mathrm{m}$ (I). 


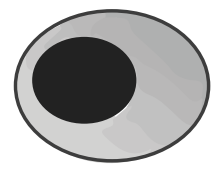

Pluripotent stem cell

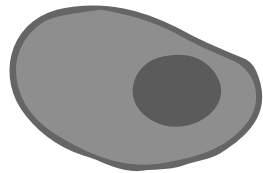

Cardiac
progenitor cell
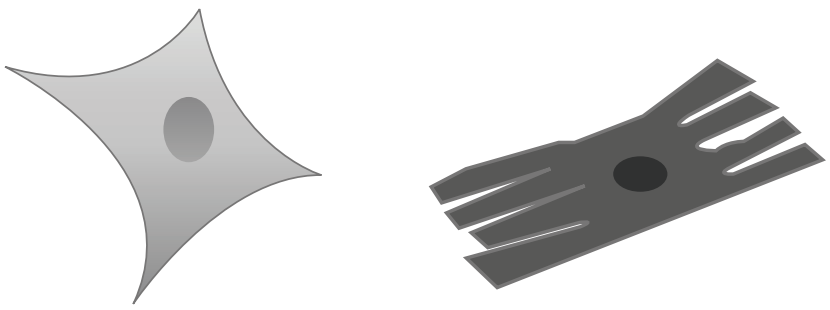

Immature

cardiomyocyte

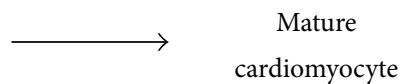

\begin{tabular}{|l|}
\hline Nkx2.5 \\
GATA4 \\
MEF2C \\
TBX5 \\
\hline
\end{tabular}

\begin{tabular}{l|}
\hline cTnT \\
cTnI \\
GJA1 \\
ACTN1 \\
MHC
\end{tabular}

Myofibrillar organization

Electrical transmission

Calcium handling

Figure 6: Sequential steps in cardiac differentiation in vitro from pluripotent stem cells to functional cardiomyocytes [70]. Cardiac development starts with the commitment of undifferentiated pluripotent stem cells of the inner cell mass of blastocysts to mesodermal restricted derivatives during embryonic development. Typical markers and characteristics for the different cell types are indicated. Structural and functional maturation is not well understood. Maturation might be provoked by hormones, electrical and mechanical stimulation, and organization in 3D engineered heart tissues (EHTs).

\author{
Abbreviations \\ 3D: $\quad$ Three-dimensional \\ ACTN1: Actinin, alpha 1 \\ ASCs: $\quad$ Adult stem cells \\ BLI: $\quad$ Bioluminescence imaging \\ CDH1: $\quad$ E-cadherin \\ CTE: $\quad$ Cardiac tissue engineering \\ cTnI: Cardiac Troponin I \\ ESCs: $\quad$ Embryonic stem cells \\ GJA1: $\quad$ Gap junction protein, alpha 1 (Connexin 43) \\ LAD: $\quad$ Left anterior descending artery \\ MEF2C: $\quad$ Myocyte enhancer factor 2C \\ MI: Myocardial infarction \\ MSCs: Mesenchymal stem cells \\ PCI: $\quad$ Percutaneous coronary intervention \\ PCLMA: poly(caprolactone 2-(methacryloyloxy)ethyl \\ ester) \\ PEA: $\quad$ poly(ethyl acrylate) \\ RT-PCR: Reverse transcription polymerase chain \\ reaction \\ SNAI1: $\quad$ Snail family zinc finger 1 \\ subATDPCs: Subcutaneous adipose tissue derived \\ progenitor cells \\ TBX5: $\quad$ T-box transcription factor 5 \\ cTnT: $\quad$ Troponin T2.
}

\section{Conflict of Interests}

The authors declare that there is no conflict of interests regarding the publication of this paper.

\section{Authors' Contribution}

C. Castells-Sala, A. Vallés-Lluch, and C. Soler-Botija contributed equally to this work.

\section{Acknowledgments}

The authors wish to thank the Department of Cardiac Surgery (Hospital Germans Trias i Pujol, Badalona) for their collaboration in obtaining human samples, Dr. Bagó for his kind contribution in the cell transduction process and BLI analysis, and Joan Gilabert from Biomaterials Laboratory (GEMAT, IQS-School of Engineering) who kindly helped them with wettability measurements. The research leading to these results has received funding from the European Union Seventh Framework Programme (FP7/2007-2013) under Grant agreement no. 229239. This work was also supported by Grants from Ministerio de Educación y Ciencia (SAF2011-30067-C02-01 and M. Arnal-Pastor FPU 2009-1870 grant), Red de Terapia Celular-TerCel (RD12/0019/0029), Red Cardio-vascular (RD12/0042/0047), and Fundació La Marató de TV3 (122232).

\section{References}

[1] C. Stamm, B. Nasseri, Y.-H. Choi, and R. Hetzer, "Cell therapy for heart disease: great expectations, as yet unmet," Heart Lung and Circulation, vol. 18, no. 4, pp. 245-256, 2009.

[2] J.-P. Karam, C. Muscari, and C. N. Montero-Menei, "Combining adult stem cells and polymeric devices for tissue engineering in 
infarcted myocardium," Biomaterials, vol. 33, no. 23, pp. 5683$5695,2012$.

[3] S. Fernandes, S. Kuklok, J. McGonigle, H. Reinecke, and C. E. Murry, "Synthetic matrices to serve as niches for muscle cell transplantation," Cells Tissues Organs, vol. 195, no. 1-2, pp. 4859, 2011.

[4] A. N. Patel and J. A. Genovese, "Stem cell therapy for the treatment of heart failure," Current Opinion in Cardiology, vol. 22, no. 5, pp. 464-470, 2007.

[5] J. A. Genovese, M. Cortes-Morichetti, E. Chachques, G. Frati, A. N. Patel, and J. C. Chachques, "Cell based approaches for myocardial regeneration and artificial myocardium," Current Stem Cell Research and Therapy, vol. 2, no. 2, pp. 121-127, 2007.

[6] K. O. Lui, L. Bu, R. A. Li, and C. W. Chan, "Pluripotent stem cell-based heart regeneration: from the developmental and immunological perspectives," Birth Defects Research Part CEmbryo Today, vol. 96, no. 1, pp. 98-108, 2012.

[7] L. S. Abdelli, H. Merino, C. M. Rocher, and D. K. Singla, "Cell therapy in the heart," Canadian Journal of Physiology and Pharmacology, vol. 90, no. 3, pp. 307-315, 2012.

[8] J. Hoover-Plow and Y. Gong, "Challenges for heart disease stem cell therapy," Vascular Health and Risk Management, vol. 8, no. 1, pp. 99-113, 2012.

[9] K. G. Oldroyd, C. Berry, and J. Bartunek, "Myocardial repair and regeneration: bone marrow or cardiac stem cells?" Molecular Therapy, vol. 20, no. 6, pp. 1102-1105, 2012.

[10] M. Gnecchi, P. Danieli, and E. Cervio, "Mesenchymal stem cell therapy for heart disease," Vascular Pharmacology, vol. 57, no. 1, pp. 48-55, 2012.

[11] J. Liu, Z. Zhang, Y. Liu et al., "Generation, characterization, and potential therapeutic applications of cardiomyocytes from various stem cells," Stem Cells and Development, vol. 21, no. 12, pp. 2095-2110, 2012.

[12] J. R. Venugopal, M. P. Prabhakaran, S. Mukherjee, R. Ravichandran, K. Dan, and S. Ramakrishna, "Biomaterial strategies for alleviation of myocardial infarction," Journal of the Royal Society Interface, vol. 9, no. 66, pp. 1-19, 2012.

[13] D. M. Clifford, S. A. Fisher, S. J. Brunskill et al., "Long-term effects of autologous bone marrow stem cell treatment in acute myocardial infarction: factors that may influence outcomes," PLoS ONE, vol. 7, no. 5, Article ID e37373, 2012.

[14] R. H. Lee, B. Kim, I. Choi et al., "Characterization and expression analysis of mesenchymal stem cells from human bone marrow and adipose tissue," Cellular Physiology and Biochemistry, vol. 14, no. 4-6, pp. 311-324, 2004.

[15] A. A. Qayyum, M. Haack-Sørensen, A. B. Mathiasen, E. Jørgensen, A. Ekblond, and J. Kastrup, "Adipose-derived mesenchymal stromal cells for chronic myocardial ischemia (MyStromalCell Trial): study design," Regenerative Medicine, vol. 7, no. 3, pp. 421-428, 2012.

[16] X. Bai, J. Ma, Z. Pan et al., "Electrophysiological properties of human adipose tissue-derived stem cells," American Journal of Physiology: Cell Physiology, vol. 293, no. 5, pp. C1539-C1550, 2007.

[17] N. Tandon, B. Goh, A. Marsano et al., "Alignment and elongation of human adipose-derived stem cells in response to directcurrent electrical stimulation," in Proceedings of the Annual International Conference of the IEEE Engineering in Medicine and Biology Society (EMBC '09), pp. 6517-6521, 2009.

[18] M. Rigol, N. Solanes, J. Farré et al., "Effects of adipose tissuederived stem cell therapy after myocardial infarction: impact of the route of administration," Journal of Cardiac Failure, vol. 16, no. 4, pp. 357-366, 2010.

[19] V. Planat-Bénard, C. Menard, M. André et al., "Spontaneous cardiomyocyte differentiation from adipose tissue stroma cells," Circulation Research, vol. 94, no. 2, pp. 223-229, 2004.

[20] B. Weber, S. M. Zeisberger, and S. P. Hoerstrup, "Prenatally harvested cells for cardiovascular tissue engineering: fabrication of autologous implants prior to birth," Placenta, vol. 32, no. 4, pp. S316-S319, 2011.

[21] M. Cortes-Morichetti, G. Frati, O. Schussler et al., "Association between a cell-seeded collagen matrix and cellular cardiomyoplasty for myocardial support and regeneration," Tissue Engineering, vol. 13, no. 11, pp. 2681-2687, 2007.

[22] J. C. Chachques, "Development of bioartificial myocardium using stem cells and nanobiotechnology templates," Cardiology Research and Practice, vol. 2011, Article ID 806795, 7 pages, 2011.

[23] J. C. Chachques, M. M. Pradas, A. Bayes-Genis, and C. Semino, "Creating the bioartificial myocardium for cardiac repair: challenges and clinical targets," Expert Review of Cardiovascular Therapy, vol. 11, no. 12, pp. 1701-1711, 2013.

[24] B. C. Karikkineth and W.-H. Zimmermann, "Myocardial tissue engineering and heart muscle repair," Current Pharmaceutical Biotechnology, vol. 14, no. 1, pp. 4-11, 2013.

[25] B. Demirbag, P. Y. Huri, G. T. Kose, A. Buyuksungur, and V. Hasirci, "Advanced cell therapies with and without scaffolds," Biotechnology Journal, vol. 6, no. 12, pp. 1437-1453, 2011.

[26] C. Soler-Botija, J. R. Bagó, and A. Bayes-Genis, "A bird'seye view of cell therapy and tissue engineering for cardiac regeneration," Annals of the New York Academy of Sciences, vol. 1254, no. 1, pp. 57-65, 2012.

[27] M. Pérez Olmedilla, N. Garcia-Giralt, M. M. Pradas et al., "Response of human chondrocytes to a non-uniform distribution of hydrophilic domains on poly (ethyl acrylate-cohydroxyethyl methacrylate) copolymers," Biomaterials, vol. 27, no. 7, pp. 1003-1012, 2006.

[28] A. J. Campillo-Fernandez, S. Pastor, M. Abad-Collado et al., "Future design of a new keratoprosthesis. Physical and biological analysis of polymeric substrates for epithelial cell growth," Biomacromolecules, vol. 8, no. 8, pp. 2429-2436, 2007.

[29] A. J. Campillo-Fernández, R. E. Unger, K. Peters et al., "Analysis of the biological response of endothelial and fibroblast cells cultured on synthetic scaffolds with various hydrophilic/ hydrophobic ratios: influence of fibronectin adsorption and conformation," Tissue Engineering, Part A, vol. 15, no. 6, pp. 1331-1341, 2009.

[30] M. Soria, C. Marti, M. Salmero et al., "Survival and differentiation of embryonic neural explants on different biomaterials," Journal of Biomedical Materials Research Part A, vol. 79, pp. 495$502,2006$.

[31] C. Martínez-Ramos, A. Vallés-Lluch, J. M. G. Verdugo et al., "Channeled scaffolds implanted in adult rat brain," Journal of Biomedical Materials Research Part A, vol. 100, no. 12, pp. 32763286, 2012.

[32] P. Rico, J. C. R. Hernández, D. Moratal, G. Altankov, M. M. Pradas, and M. Salmerón-Sánchez, "Substrate-induced assembly of fibronectin into networks: influence of surface chemistry and effect on osteoblast adhesion," Tissue Engineering Part A, vol. 15, no. 11, pp. 3271-3281, 2009.

[33] J. M. Soria, M. Sancho-Tello, M. A. G. Esparza et al., "Biomaterials coated by dental pulp cells as substrate for neural stem cell differentiation," Journal of Biomedical Materials Research, Part A, vol. 97, no. 1, pp. 85-92, 2011. 
[34] J. L. Escobar Ivirico, E. Costa Martínez, M. Salmerón Sánchez, I. Muñoz Criado, J. L. Gómez Ribelles, and M. Monleón Pradas, "Structure and properties of methacrylate-endcapped caprolactone networks with modulated water uptake for biomedical applications," Journal of Biomedical Materials Research, Part B, Applied Biomaterials, vol. 83, no. 1, pp. 266-275, 2007.

[35] J. L. E. Ivirico, M. Salmerón-Sánchez, J. L. G. Ribelles et al., "Proliferation and differentiation of goat bone marrow stromal cells in 3D scaffolds with tunable hydrophilicity," Journal of Biomedical Materials Research Part B: Applied Biomaterials, vol. 91, no. 1, pp. 277-286, 2009.

[36] J. E. Ivirico, G. G. Ferrer, E. Novella-Maestre, A. Ruiz-Sauri, M. M. Pradas, and C. Carda, "In vivo response of methacrylate endcapped caprolactone scaffolds," Regenerative Medicine, vol. 2, no. 5, p. 616, 2007.

[37] I. R. Dégano, L. Quintana, M. Vilalta et al., "The effect of selfassembling peptide nanofiber scaffolds on mouse embryonic fibroblast implantation and proliferation," Biomaterials, vol. 30, no. 6, pp. 1156-1165, 2009.

[38] J. Kisiday, M. Jin, B. Kurz et al., "Self-assembling peptide hydrogel fosters chondrocyte extracellular matrix production and cell division: implications for cartilage tissue repair," Proceedings of the National Academy of Sciences of the United States of America, vol. 99, no. 15, pp. 9996-10001, 2002.

[39] C. E. Semino, J. R. Merok, G. G. Crane, G. Panagiotakos, and S. Zhang, "Functional differentiation of hepatocyte-like spheroid structures from putative liver progenitor cells in threedimensional peptide scaffolds," Differentiation, vol. 71, no. 4-5, pp. 262-270, 2003.

[40] D. A. Narmoneva, R. Vukmirovic, M. E. Davis, R. D. Kamm, and R. T. Lee, "Endothelial cells promote cardiac myocyte survival and spatial reorganization: implications for cardiac regeneration," Circulation, vol. 110, no. 8, pp. 962-968, 2004.

[41] E. Genové, C. Shen, S. Zhang, and C. E. Semino, “The effect of functionalized self-assembling peptide scaffolds on human aortic endothelial cell function," Biomaterials, vol. 26, no. 16, pp. 3341-3351, 2005.

[42] E. Garreta, E. Genové, S. Borrós, and C. E. Semino, "Osteogenic differentiation of mouse embryonic stem cells and mouse embryonic fibroblasts in a three-dimensional self-assembling peptide scaffold," Tissue Engineering, vol. 12, no. 8, pp. 22152227, 2006.

[43] L. Quintana, T. Fernández Muiños, E. Genové, M. D. M. Olmos, S. Borrós, and C. E. Semino, "Early tissue patterning recreated by mouse embryonic fibroblasts in a three-dimensional environment," Tissue Engineering-Part A, vol. 15, no. 1, pp. 45-54, 2009.

[44] J. Wu, N. Marí-Buyé, T. F. Muiños, S. Borrós, P. Favia, and C. E. Semino, "Nanometric self-assembling peptide layers maintain adult hepatocyte phenotype in sandwich cultures," Journal of Nanobiotechnology, vol. 8, article 29, 2010.

[45] A. Vallés-Lluch, M. Arnal-Pastor, C. Martínez-Ramos et al., "Combining self-assembling peptide gels with threedimensional elastomer scaffolds," Acta Biomaterialia, vol. 9, no. 12, pp. 9451-9460, 2013.

[46] C. E. Semino, "Can we build artificial stem cell compartments?" Journal of Biomedicine and Biotechnology, vol. 2003, no. 3, pp. 164-169, 2003.

[47] J. C. Rodríguez Hernández, Á. Serrano Aroca, J. L. Gómez Ribelles, and M. Monleón Pradas, "Three-dimensional nanocomposite scaffolds with ordered cylindrical orthogonal pores,"
Journal of Biomedical Materials Research, Part B, Applied Biomaterials, vol. 84, no. 2, pp. 541-549, 2008.

[48] J. M. Estellés, I. Krakovsky, J. C. R. Hernández, A. M. Piotrowska, and M. M. Pradas, "Mechanical properties of porous crosslinked poly(ethyl-acrylate) for tissue engineering," Journal of Materials Science, vol. 42, no. 20, pp. 8629-8635, 2007.

[49] M. Arnal-Pastor, A. Vallés-Lluch, M. Keicher, and M. M. Pradas, "Coating typologies and constrained swelling of hyaluronic acid gels within scaffold pores," Journal of Colloid and Interface Science, vol. 361, no. 1, pp. 361-369, 2011.

[50] R. Brígido Diego, M. Pérez Olmedilla, A. Serrano Aroca et al., "Acrylic scaffolds with interconnected spherical pores and controlled hydrophilicity for tissue engineering," Journal of Materials Science: Materials in Medicine, vol. 16, no. 8, pp. 693698, 2005.

[51] J. Cinca, M. Warren, A. Rodríguez-Sinovas et al., "Passive transmission of ischemic ST segment changes in low electrical resistance myocardial infarct scar in the pig," Cardiovascular Research, vol. 40, no. 1, pp. 103-112, 1998.

[52] Y. Salazar, R. Bragos, O. Casas, J. Cinca, and J. Rosell, "Transmural versus nontransmural in situ electrical impedance spectrum for healthy, ischemic, and healed myocardium," IEEE Transactions on Biomedical Engineering, vol. 51, no. 8, pp. 14211427, 2004.

[53] A. Bayes-Genis, C. Soler-Botija, J. Farré et al., "Human progenitor cells derived from cardiac adipose tissue ameliorate myocardial infarction in rodents," Journal of Molecular and Cellular Cardiology, vol. 49, no. 5, pp. 771-780, 2010.

[54] O. M. Martínez-Estrada, Y. Muñoz-Santos, J. Julve, M. Reina, and S. Vilaró, "Human adipose tissue as a source of Flk-1+ cells: new method of differentiation and expansion," Cardiovascular Research, vol. 65, no. 2, pp. 328-333, 2005.

[55] M. Vilalta, C. Jorgensen, I. R. Dégano et al., "Dual luciferase labelling for non-invasive bioluminescence imaging of mesenchymal stromal cell chondrogenic differentiation in demineralized bone matrix scaffolds," Biomaterials, vol. 30, no. 28, pp. 4986-4995, 2009.

[56] Q.-Z. Chen, S. E. Harding, N. N. Ali, A. R. Lyon, and A. R. Boccaccini, "Biomaterials in cardiac tissue engineering: ten years of research survey," Materials Science and Engineering R: Reports, vol. 59, no. 1-6, pp. 1-37, 2008.

[57] W. Hiesinger, M. J. Brukman, R. C. McCormick et al., "Myocardial tissue elastic properties determined by atomic force microscopy after stromal cell-derived factor $1 \alpha$ angiogenic therapy for acute myocardial infarction in a murine model," Journal of Thoracic and Cardiovascular Surgery, vol. 143, no. 4, pp. 962-966, 2012.

[58] G. Xu, L. Zhang, G. Ren et al., "Immunosuppressive properties of cloned bone marrow mesenchymal stem cells," Cell Research, vol. 17, no. 3, pp. 240-248, 2007.

[59] M. Dominici, K. Le Blanc, I. Mueller et al., "Minimal criteria for defining multipotent mesenchymal stromal cells. The International Society for Cellular Therapy position statement," Cytotherapy, vol. 8, no. 4, pp. 315-317, 2006.

[60] A. Llucià-Valldeperas, B. Sanchez, C. Soler-Botija et al., "Electrical stimulation of cardiac adipose tissue-derived progenitor cells modulates cell phenotype and genetic machinery," Journal of Tissue Engineering and Regenerative Medicine, 2013.

[61] C. Castells-Sala and C. E. Semino, "Biomaterials for stem cell culture and seeding for the generation and delivery of cardiac myocytes," Current Opinion in Organ Transplantation, vol. 17, no. 6, pp. 681-687, 2012. 
[62] M. H. van Marion, N. A. M. Bax, A. C. C. van Spreeuwel, D. W. J. van der Schaft, and C. V. C. Bouten, "Materialbased engineering strategies for cardiac regeneration," Current Pharmaceutical Design, vol. 20, no. 12, pp. 2057-2068, 2014.

[63] A. Shafy, T. Fink, V. Zachar, N. Lila, A. Carpentier, and J. C. Chachques, "Development of cardiac support bioprostheses for ventricular restoration and myocardial regeneration," European Journal of Cardio-Thoracic Surgery, vol. 43, no. 6, pp. 1211-1219, 2013.

[64] M. A. Laflamme and C. E. Murry, "Heart regeneration," Nature, vol. 473, no. 7347, pp. 326-335, 2011.

[65] J. C. Chachques, J. C. Trainini, N. Lago, M. Cortes-Morichetti, O. Schussler, and A. Carpentier, "Myocardial Assistance by Grafting a New Bioartificial Upgraded Myocardium (MAGNUM trial): clinical feasibility study," Annals of Thoracic Surgery, vol. 85, no. 3, pp. 901-908, 2008.

[66] L. Qian, W. Shim, Y. Gu et al., "Hemodynamic contribution of stem cell scaffolding in acute injured myocardium," Tissue Engineering A, vol. 18, no. 15-16, pp. 1652-1663, 2012.

[67] M. Arnal-Pastor, C. Martínez Ramos, M. Pérez Garnés, M. Monleón Pradas, and A. Vallés Lluch, "Electrospun adherentantiadherent bilayered membranes based on cross-linked hyaluronic acid for advanced tissue engineering applications," Materials Science and Engineering C, vol. 33, no. 7, pp. 40864093, 2013.

[68] L. A. Geddes and L. E. Baker, "The specific resistance of biological material - a compendium of data for the biomedical engineer and physiologist," Medical and Biological Engineering, vol. 5, no. 3, pp. 271-293, 1967.

[69] M. A. Fallert, M. S. Mirotznik, S. W. Downing et al., "Myocardial electrical impedance mapping of ischemic sheep hearts and healing aneurysms," Circulation, vol. 87, no. 1, pp. 199-207, 1993.

[70] L. Cyganek, "Cardiac progenitor cells and their therapeutic application for cardiac repair," Journal of Clinical \& Experimental Cardiology, S11, article 8, 2013.

[71] T. K. Ghosh, E. A. Packham, A. J. Bonser, T. E. Robinson, S. J. Cross, and J. D. Brook, "Characterization of the TBX5 binding site and analysis of mutations that cause Holt-Oram syndrome," Human Molecular Genetics, vol. 10, no. 18, pp. 1983-1994, 2001.

[72] C. Wang, D. Cao, Q. Wang, and D.-Z. Wang, "Synergistic activation of cardiac genes by myocardin and Tbx5," PLOS ONE, vol. 6, no. 8, Article ID e24242, 2011.

[73] M. M. Lockhart, E. E. Wirrig, A. L. Phelps et al., "Norris R a and Wessels A 2013 Mef2c regulates transcription of the extracellular matrix protein cartilage link protein 1 in the developing murine heart," PLoS ONE, vol. 8, no. 2, Article ID e57073, 2013.

[74] M. Perán, J. A. Marchal, E. López et al., "Human cardiac tissue induces transdifferentiation of adult stem cells towards cardiomyocytes," Cytotherapy, vol. 12, no. 3, pp. 332-337, 2010.

[75] I. P. G. Moskowitz, A. Pizard, V. V. Patel et al., "The TBox transcription factor Tbx 5 is required for the patterning and maturation of the murine cardiac conduction system," Development, vol. 131, no. 16, pp. 4107-4116, 2004.

[76] J. Wilson-Rawls, J. D. Molkentin, B. L. Black, and E. N. Olson, "Activated Notch inhibits myogenic activity of the MADS-Box transcription factor myocyte enhancer factor 2C," Molecular and Cellular Biology, vol. 19, no. 4, pp. 2853-2862, 1999.

[77] C. Karamboulas, G. D. Dakubo, J. Liu et al., "Disruption of MEF2 activity in cardiomyoblasts inhibits cardiomyogenesis," Journal of Cell Science, vol. 119, no. 20, pp. 4315-4321, 2006.
[78] H. Ninomiya, R. David, E. W. Damm, F. Fagotto, C. M. Niessen, and R. Winklbauer, "Cadherin-dependent differential cell adhesion in xenopus causes cell sorting in vitro but not in the embryo," Journal of Cell Science, vol. 125, no. 8, pp. 1877-1883, 2012.

[79] M. Gnecchi, H. He, N. Noiseux et al., "Evidence supporting paracrine hypothesis for Akt-modified mesenchymal stem cellmediated cardiac protection and functional improvement," The FASEB Journal, vol. 20, no. 6, pp. 661-669, 2006.

[80] I. Chimenti, R. R. Smith, T.-S. Li et al., "Relative roles of direct regeneration versus paracrine effects of human cardiospherederived cells transplanted into infarcted mice," Circulation Research, vol. 106, no. 5, pp. 971-980, 2010.

[81] A. H. S. Kumar and N. M. Caplice, "Clinical potential of adult vascular progenitor cells," Arteriosclerosis, Thrombosis, and Vascular Biology, vol. 30, no. 6, pp. 1080-1087, 2010. 

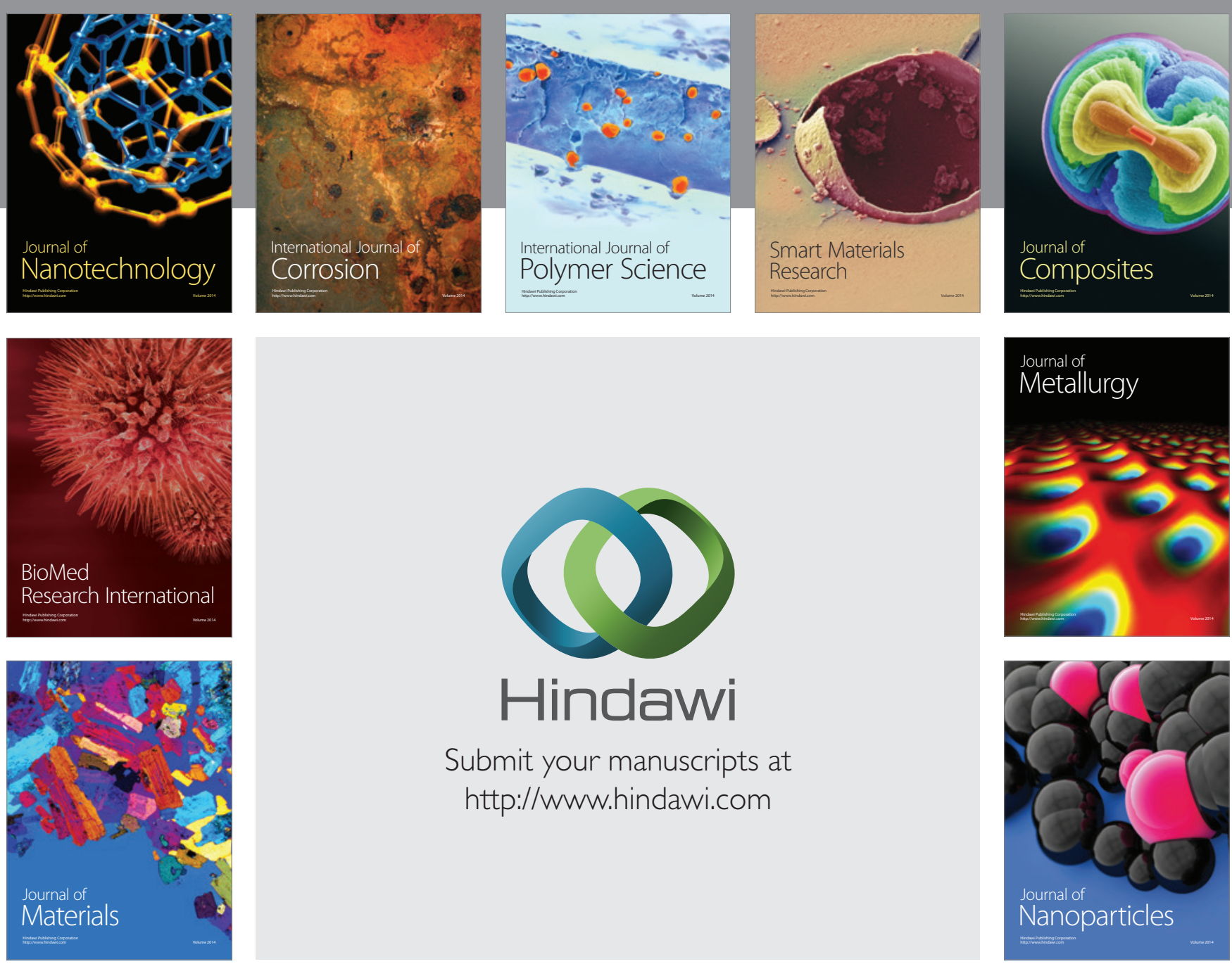

Submit your manuscripts at http://www.hindawi.com
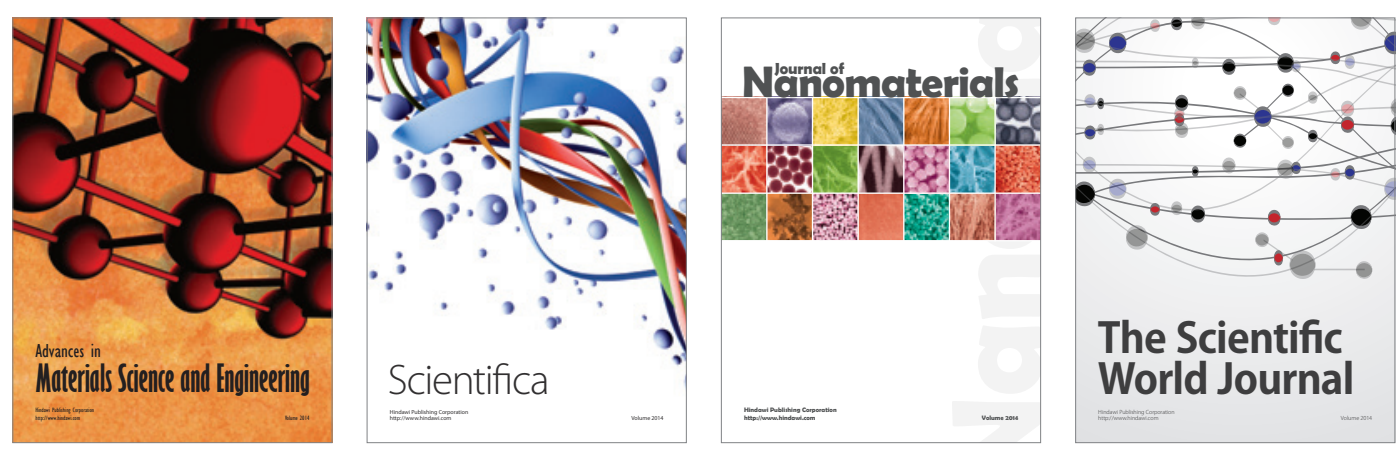

\section{The Scientific World Journal}
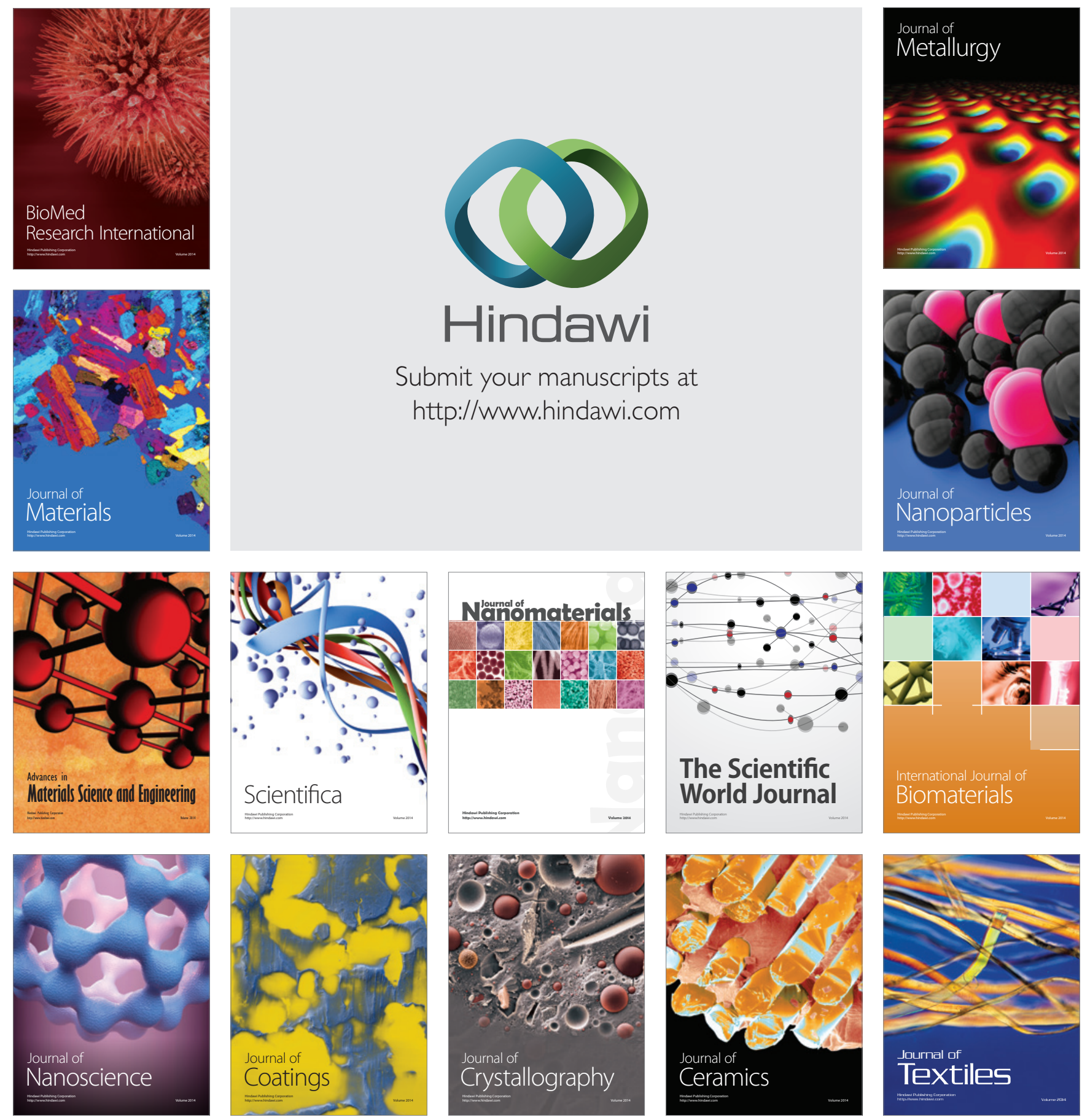